\title{
利用者の利用体験に対する態度に基づく 自然公園の管理方策
}

\author{
A Study on Natural Park Management Based on Visitor' Attitude toward Visitor Experience
}

\author{
小林昭裕* \\ Akihiro KOBAYASHI
}

摘要 : 大雪山国立公園内の 2 箇所の区域を対象に, 利用者が利用体験を重視する程度と, 利用行為に 伴うインパクトに対処する管理方策への支持やインパクトに対する不快感との関係について検討した。 利用者が示す態度の違いは区域間で小さかった。しかし, 利用体験を重視する程度と管理方策の支持 との関係は，区域間で異なり，利用者が支持する管理方策を用意するには，区域毎に利用者が示す態 度に応じた対応が求められた。また, 対人的接触へのインパクトに比べ, 利用行為が自然環境に及ぼ すインパクトについて, 対処の必要性や緊急性が高く, 利用者の不快感が強い傾向を示した。

\section{1. 緒言}

野外レクリエーションにおける利用体験とは, 利用者が望む環 境のもとで利用者が望む活動を通じて得る体験と定義づけること ができる。Driver らによれば, 風致・生態的特性や人工構築物 を含めた物理面, 他の利用者との遭遇や衝突, 行動形態などの社 交面, 情報提供や利用規制などの管理面の違いによって, 利用体 験の場となる環境は左右される ${ }^{1)}$ 。そのため, 自然公園における 利用の量的・質的変化やそれに対処する管理内容は, 環境の変化 を通じて，自然環境だけでなく利用体験に影響を及ぼす。

米国では, 良好な利用体験の確保之自然資源を保全するため, National Park Service が, VERP (Visitor Experience and Resource Protection）という概念を提示した。この概念に基 づき，試行的に，Arches National Parkにおいて，当該公園 の目的や重要性, 利用者が望む利用体験や自然資源の分析をむと に, 物理面, 社交面, 管理面の環境特性を考慮した管理を始めて いる ${ }^{6)}$ 。わが国の自然公園の管理は，米国と違い，数少ないス夕ッ フに委対られている。管理方策に対する利用者の支持がなければ, その実効性は乏しい。利用者が望む利用体験にふさわしい環境や 活動の機会を提供しつつ, 利用者から支持される管理方策を用意 する必要がある。そのため, 利用者が利用体験を重視する程度 （以下, 重視度）と, 利用体験の場となる環境での, 利用行為に 伴うインパクトに対処する管理方策への利用者の支持や，管理行 為ならびに利用行為がもたらすインパクトに対する利 用者の不快感との関係について検討することは有意義 と考えられる。

これまでの研究から，自然公園における利用体験へ の期待は, 公園区域内で異なるほか32, 利用体験への 期待が異なる場合に, 目的とする区域が異なる傾向を 示しだ)。そのため, 利用体験への重視度とインパク トに対処する管理方策への支持，インパクトに対する 不快感との関連性を検討するにあたって, その対象と なる区域を限定し，議論することが適切と考えられた。

\section{2. 調查方法}

調査対象を大雪山国立公園の登山者（以下，利用者） とし, 調查時期を利用者が年間を通じて最も多い7月 中旬から 8 月上旬とした。すべての利用者集団につい
て，集団の大きさに応じて（1～ 2 人では 1 件， $3 \sim 5$ 人では 2 件, 6 人以上では 3 件ないし 5 件を目安), 登川者にアンヶート を配布し，帰宅後に調査紙に回答し郵送するよう依頼した。調䍒 対象区域を，大雪山を中心とした区域 I，または，トムラウシ山 〜五色ヶ原を中心とした区域 II しし，区域内とその周辺でアンケー 卜を配布した（図一 1 )。配布地点, 配布日, 配布数, 回収数, 回収率を表一 1 に示した。

調查項目について，利用者の期待や動機を参考に，利用体験の 重視度および実現できない場合の不満感について 12 項目 ${ }^{4}$, Manfredo らの指摘をもとに ${ }^{5}$ ，管理方策に対する支持度合いお よび管理方策の必要性・緊急性について 9 項目，インパクトに対 する不快感および対処の必要性・緊急性について 9 項目を設けた (表一2)。質問紙に対象区域を四で示し，そこでの利用体験につ いて回答を求めた。対象区域が異なっても，C1: 他者との遭遇を 除き，設問を同じとし

た。C1 では既往研究 表ー1 アンケートの配布および回収

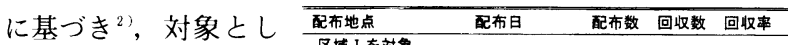
た区域内で他者との遭 遇に対し利用者が不快 に感じ始める人数の中 央値を一の位で四捨五 入した人数を示し回答

\begin{tabular}{|c|c|c|c|c|}
\hline 配布地点 & 配布日 & 配布数 & 回收数 & 回収率 \\
\hline \multicolumn{5}{|l|}{ 区域 Iを刘象 } \\
\hline 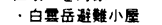 & $7 / 20-7 / 23$ & & & \\
\hline 白害岳野若指定地 & $7 / 27-7 / 29$ & 280 & 95 & 33. $9 x$ \\
\hline ·赤医第三贯溪 & $7 / 13,8 / 5,8 / 12$ & 218 & 98 & 44. $9 x$ \\
\hline \multicolumn{5}{|l|}{ 区域 几を対象 } \\
\hline \multirow{4}{*}{ 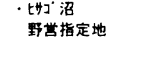 } & $7 / 14,7 / 15$ & & & \\
\hline & $7 / 19,7 / 20$ & & & \\
\hline & $8 / 1-8 / 3$ & 194 & 92 & $47.4 x$ \\
\hline & 現地回収 & & 10 & \\
\hline \multirow[t]{2}{*}{ - 沼の原 } & $8 / 5,8 / 12$ & 70 & 11 & 15. $7 \mathrm{x}$ \\
\hline & 釉部 & 762 & 306 & $40.1 \mathrm{x}$ \\
\hline
\end{tabular}

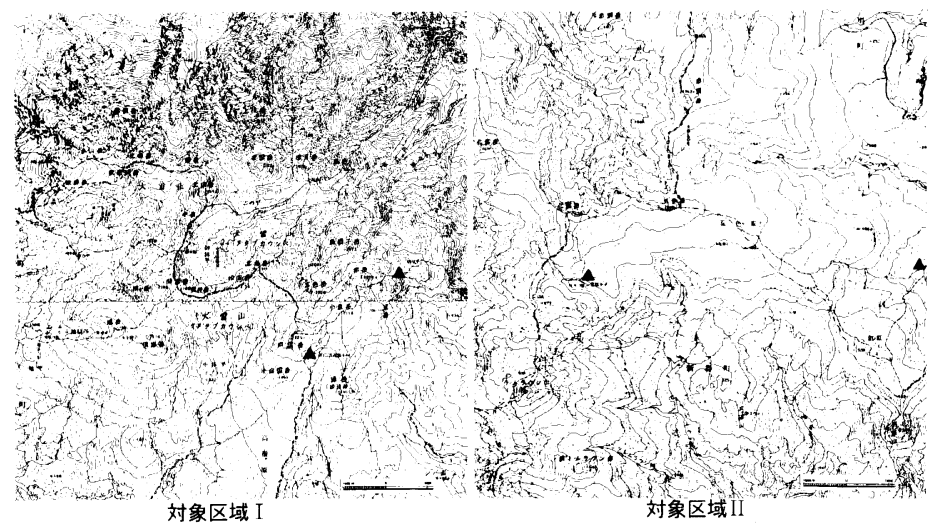

図－1 調査対象区域の範囲およびアンケート配布地点 $\boldsymbol{\Delta} \cdots$ アンケート配布地点

\footnotetext{
•専修大学北海道短期大学造園林学科
} 


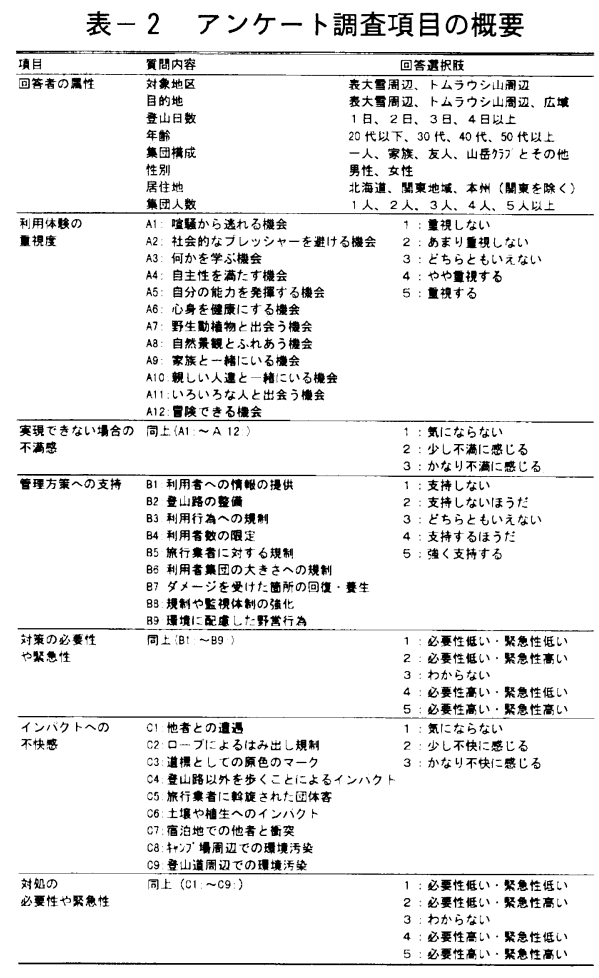

を求めた。また，必要性・緊急性への回答について，必要性之緊 急性それぞれ「高い」「よ゙ちらともいえない」「低い」に仕分けし， 必要性と緊急性に分けて分析を行った。データの解析に, 統計パッ ケージSAS Ver.6を使用した。

\section{3. 結果}

\section{（1）対象区域および回答者の属性による回答の違い}

区域を分類变数とし回答内容を分散分析した結果（表一-3）, 利用体験の重視度について，A12：冒険できる機会は区域 II， A9: 家族と一緒にいる機会は，区域 I でより重視された。利用 体験が実現しない場合の不満感について，A3：何かを学ぶ機会 とA9は, 区域Iで不満感が強く現れた。インパクトに対する管 理方策への支持や，インパクトへの不快感について，区域間で有 意差がなかった。区域間で回答者の属性を比較すると（表一4）, $\chi^{2}$ 検定の結果, 目的地, 登山日数, 集扵構成, 性別, 居住地で 有意差がみられた。区域 I では, 目的地が表大雪, 登山日数が 1 日や 2 日, 集団構成が家族, 性別が女性, 居住地が北海道の割合 が多かった。区域Iでは，目的地がトムラウシ山周辺や広域，登 山日数が 3 日や 4 日以上, 集讨構成が単独や山岳クラブ, 性別が 男性，居住地が本州（関東を除く）の割合が多かった。利用体験 への重視度や実現できない場合の不満感，インパクトに対する管 理方策への支持, インパクトに対する不快感について, 目的地, 登山日数, 年齢, 集闷構成, 性別, 居住地, 集闷人数をそれぞれ 分類変数として，一元配置の分散分析を行った（表一 3 )。有意 差がみられた項目について, 利用体験の重視度が高い, あるいは, 実現できない場合の不満感が強い，管理方策への支持が強い，イ ンパクトへの不快感が強い，傾向を示したのは以下に該当する場 合であった。目的地を大雪山周辺とした場合に A12: 冒険できる 機会を除いた項目，目的地をトムラウシ山周辺とした場合に A9: 家族と一緒にいる機会を除いた項目，登山日数が 4 日以上の場合 にA6: 心身を健康にする機会とA9: 家族と一緒にいる機会を除 いた項目，居住地が関東地方の場合に A9: 家族と一緒にいる機 会を除いた項目，集団構成が山岳クラブの場合に A1: 喧騒から 逃れる機会やA9: 家族と一緒にいる機会を除いた項目，性別が

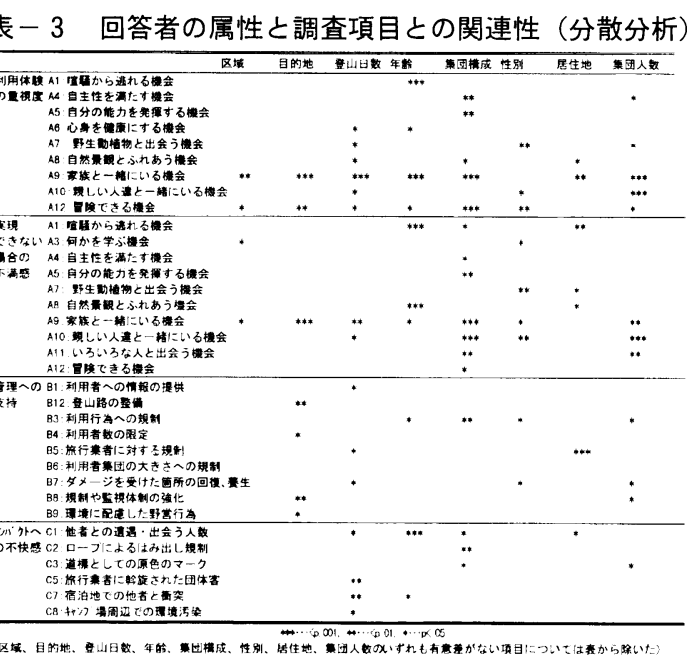

表 - 4 対象区域別にみた被験者の属性の比較

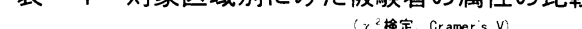

女性の場合に A10: 親しい人た ちと一緒にいる機 会とA12: 冒険で きる機会を除いた 項目，年龄が 20 代の場合に $\mathrm{A} 12$ 冒険できる機会や $\mathrm{C} 1$ : 他者との遭遇, 30 代の場合に A1: 喧騒から逃 れる機会, 40 代 以上の場合に A9: 家族と一緒にいる 機会やB3: 登山 行為への規制, 50 代以上の場合に A5：心身を健康 にする機会が該当 した。
（2）利用体験への重視度および実現できない場合の不満感 結果の（1）から区域間で有意差が認められた項目は，一部に とどまった。区域毎の回答を統合して全体の傾向をみると（図 2), A8: 自然景観とふれあう機会や A7: 野生動植物と出会う機 会を，利用体験として重視した割合（4：やや重視する，または 5: 重視する）は80\%を越えた。また，A1：喧騒から逃れる機会 やA3: 何かを学ぶ機会, A6: 心身を健康にする機会を重視した 割合も50\%を越えるなど，利用者はさまざまな利用体験を重視 する傾向を示した。一方，A12: 冒険できる機会やA9: 家族之一 緒にいる機会，A11: いろいろな人と出会う機会を重視する割合 は30\%以下で，利用体験として重視する利用者は少なかった。 利用体験が実現できない場合に不満に感じる（2：少し不満に感 じる，または，3：かなり不満に感じる）割合について，利用体 験を重視する割合が多い項目では，実現できない場合に不満に感 じる割合が多い傾向を示した。

\section{（3）管理方策への支持度合いおよびその必要性や緊急性}

結果の（1）で区域間で有意差が認められた項目がないことか ら，区域每の回答 を統合して全体の 傾向をみると(四 3), B3: 利用行 為への規制，B7: ダメージを受けた 筒所の回復・養生, B9: 環境に配慮し た野営行為につい て, 回答者の 75 \%強が支持した ( 4 : 支持するほ うだまたは，5： 強く支持する)。 一方, B4: 利用者 数の限定や $\mathrm{B} 6$ : 利用集甩の大きさ の限定を支持した 割合は $50 \%$ を下 回った。また，管 理方策を支持する

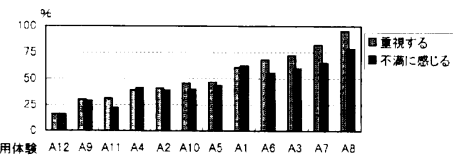

図ー2 利用体験を重視する割合と実現できない場合に不满 を感じる割合
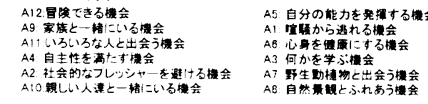

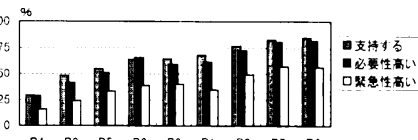

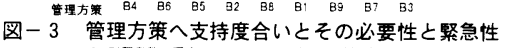

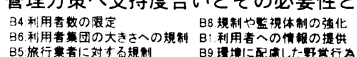

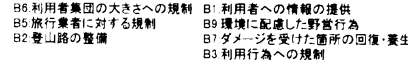

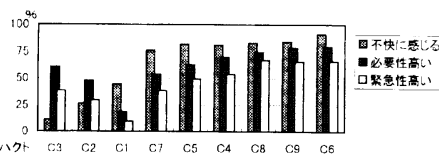

図-4 利用インパクトへの不満感とその対策の必要性と緊 急性

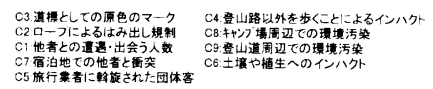




\section{表一 5 利用体験の重視度と管理の支持度合いとの関連性}

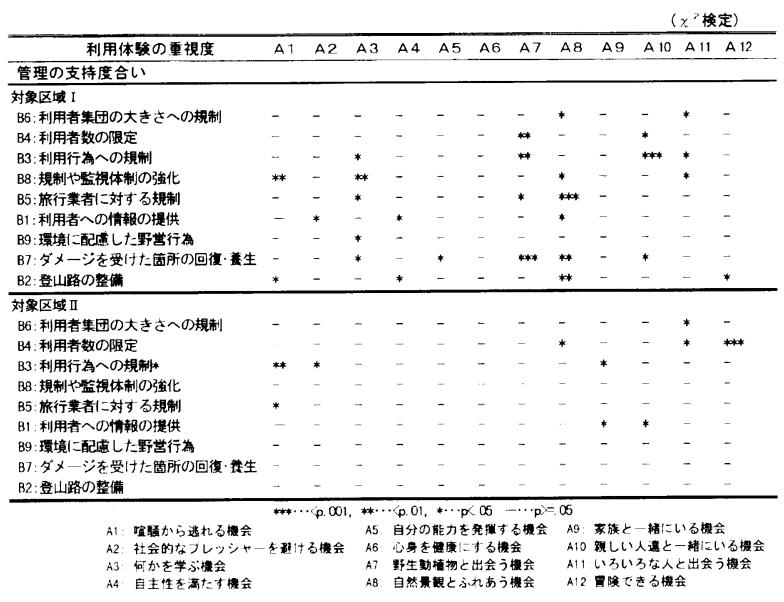

割合が多い項目では，その必要性や緊急性を高いとみなす割合が 多い傾们を示した。

（4）インパクトへの不快感と, その対策の必要性や緊急性

結果の（1）で区域間で有意差が認められた項月がないことから, 区域毎の回答を統合して全体の傾向をみると（図-4），C1：他 者との遭遇や C2：ロープによる規制，C3：原色のマークを除い て, 回答者の $75 \%$ 以上が, 利用行為がもたらすインパクトに不 快感を覚えた（2：少し不快に感じる，または，3：かなり不快 に感じる)。なかでも， C6: 土壤や植生へのインパクトや C9: 登 山道周辺での環境污染, $\mathrm{C} 8$ : キャンプ 場周辺での環境污染につ いて，不快に感じる割合は回答者の $80 \%$ を越えるとともに，対 処の必要性が高い之みなす割合は 70\%を越えた。C1 や C2，C3， C7, C5 を除き，不快を感じる割合が多い項目では，対処の必要 性や緊急性を高いとみなす割合む同じょうに多かった。C1: 他者 との遭遇や C7: 宿泊地での他者との衝突（過密状況や迷惑な利 用行為)，C5: 旅行業者に斡旋された団体客について，不快を感 じる割合に比へ，その対策の必要性や緊急性を高いとみなす割合 が相対的に少なかった。一方, C2 や C3 に示される管理行為に ついて, 不快を感じる割合は少ないが, 対処の必要性を高いとみ なす割合が相対的に多かった。

\section{（5）利用体験の重視度と，管理方策への支持との関係}

区域每に，利用体験の重視度之利用体験に伴うインパクトに対 する管理方策への支持との関係について， $\chi^{2}$ 検定した結果（表一 5 ), 区域 I では, 区域 I に比べ, 利用体験への重視度の違いに よって管理方策への支持が異なる場合が多かった。

関連内容をみる上，区域 Iでは，A4：自主性を満たす機会を 除き，大半は，利用体験を重視するほど，管理方策を強く支持す る傾向を示した。利用体験の中でも，A3: 何かを学ぶ機会や A7: 野生動植物之出会う機会, A8: 自然景観とふれあう機会につい て，有意差がみられ，これらを重視する場合，B5: 旅行業者に対 する規制，B7：ダメージを受けた個所の回復・養生への支持が強 いほか，B4: 利用者数の限定や B3: 利用行為への規制, B8: 規 制や監視体制の強化への支持が強い傾向を示した。区域Iでは, 利用体験への重視度の違いに関わらず，管理方策への支持に有意 差がない場合が大半であった。有意差がみられた場合でも，利用 体験を重視するほど，支持が強い傾向を示すとは限らなかった。 たとえば，A1: 椬騒から逃れる機会やA2: 社会的なプレッシャ を避ける機会を重視する場合，B3: 利用行為への規制を支持しな い傾向を示した。

（6）利用体験の重視度と, インパクトへの不快感との関係

区域每に，利用体験の重視度とインパクトへの不快感との関係 について， $\chi^{2}$ 検定した結果（表一6），有意差が認められた項目
表 -6 利用体験の重視度とインパクトへの不快感との関連性

\begin{tabular}{|c|c|c|c|c|c|c|c|c|c|c|c|}
\hline & & & & & & & & \multicolumn{4}{|c|}{$\left(x^{2}\right.$ 㛟定) } \\
\hline 利用体の重視度 & A1 & $A_{2}$ & $\mathrm{~A} 3$ & A4 & A5 & $A 6$ & A7 & $A 8$ & $A 9 A$ & $\mathrm{~A} 10 \mathrm{~A}$ & A 11 A 12 \\
\hline \multicolumn{12}{|l|}{ インバクトへの不快感 } \\
\hline \multicolumn{12}{|l|}{ 対象区域 I } \\
\hline C2:ローフによるはみみ出し規制 & * & & & & & & & & - & - & \\
\hline C3:道楎としての原色のマーク & $*$ & & - & & - & - & - & - & - & - & \\
\hline C1:他者との遭週·出会う人数 & * & * & - & - & - & & & - & & & - \\
\hline 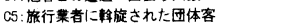 & - & & - & - & - & - & - & * & * & * & - \\
\hline 67:宿泊地ての他者と野突 & & & - & - & - & - & & & & & - \\
\hline C8:蚁プ場周边ての瓄填污染 & - & & - & & - & - & & & & & * \\
\hline CA:登山路以外を步くことによスインパクト & - & & & & & & * & - & - & * & - \\
\hline 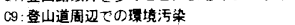 & - & - & - & * & - & & - & * & - & - & - \\
\hline C6:土堪や植生へのインハハクト & - & & - & & & & & & & & - \\
\hline \multicolumn{12}{|l|}{ 对象区域 II } \\
\hline C2:ロープによるはみみ出し䂓制 & * & & * & & & & & & - & - & - \\
\hline C3:道㮏としての原色のマーク & - & & & - & - & - & - & - & - & - & - \\
\hline C1:他者との遭通·出会う人数 & & & & & & - & - & - & - & - & \\
\hline 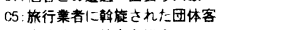 & - & & - & & - & - & - & & - & - & - \\
\hline C7:宿泊地ての他者と䒄突 & - & & - & & - & & - & - & - & * & - \\
\hline 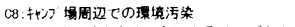 & - & & - & - & - & - & - & & & - & * \\
\hline C4:登山路以外を歩くことによるインバクト & & & & - & - & - & & - & - & * & - \\
\hline $99:$ 登山道周边飞の渗境污染 & - & - & - & - & - & - & - & * & - & - & - \\
\hline c6:土塔や植生へのインバクト & * & - & - & - & - & - & - & - & - & - & + \\
\hline
\end{tabular}

は少なかった。区域 II に比べ，区域 I では，利用体験への重視度 が違うとインパクトに対する不快感が異なる場合がやや多かった。 区域 Iについて，A1やA2 など対人的ストレスから開放を重視 する場合, $\mathrm{C} 1$ : 他者との遭遇への不快感が強い傾向を示した。 A 9 や A 10 など利用者同士の交流を重視する場合，C5や C7 にみ られる利用者同士の精神的摩擦に対する不快感が強い傾问を示し た。A7や $\mathrm{A} 8$ など自然との接触を重視する場合, 自然環境へのイ ンパクトに対する不快感が強い傾向を示した。有意差がある場合, 区域を問わず，利用体験を重視するほど不快感を覚える傾向が強 まった。

\section{4. 考察}

結果の（1）から, 区域間で, 利用体験の重視度㧍よび実現で きない場合の不満感に有意差がみられた場合は一部の利用体験 （A3，A9，A12）にとどまった。回答者の属性について区域間で 有意差がみられる目的地または登山日数, 集闷構成, 性別, 居住 地之， A3，A9，A12 とは有意な関連を示した。管理方策への支 持度，インパクトへの不快感については区域間で有意差がなかっ た。このように区域間で, 差異が認められなかった背景として, 回答を求めた区域之, 自分が登山した区域を, 回答者が弁別して 回答しずらいなど, アンケートの設問内容や提示方法を含め調查 方法に対する検討が不十分であった点や, 区域每の回答者の属性 の違いによる影響があると考えられる。また, 回答者の属性が異 なる場合, 利用体験の重視度, 利用体験を実現できない場合の不 満感, 管理方策への支持度, インパクトへの不快感に有意差がみ られた。利用体験に対する利用者の受け止め方は, 年齢差や性別, 居住地など個人的素因や, 集闷構成や目的地, 集団人数など行動 形態的素因によって左右される面があるといえよう。

結果の（2）から，区域を問わず，利用者は自然との知的・感 覚的接触や社会的ストレスからの開放, 学習や健康を通じた自己 実現などの利用体験を重視したといえる。利用者は様々な利用体 験を重視することから, 個々の利用体験の実現化では, その内容 によって相互に相容れない面もあり, 支障が生じない対応が必要 であろう。結果の（3）から, 環境に配慮した野営行為や利用行 為への規制など, 自然環境を保全するための予防的対処や現状保 全, ダメージを受けた筒所の回復・養生など保護・回復への支持 やその必要性が広く認めれた。一方, 利用者数の限定や利用集団 の大きさの限定など，利用の量的規制を支持する人が少なく, 対 策の必要性や緊急性を認める人も少なかった。結果の（4）から, 土袞や植生へのインパクトや登山道周辺掞よびキャンプ 場周辺 での環境污染など, 利用行為による自然環境への影響に対し, 多 くの利用者は，不快に感じるとともに対処の必要性を認めていた。 
他者との出会いや宿泊地での他者との衝突などに象徵される他の 利用者之の精神的摩擦，旅行業者に斡旋された団体客に象徵さ れる多人数集甩の利用形態について, 不快を感じる割合に比べ, 対処の必要性や緊急性が高いとする割合は少なかった。管理方策 への支持やその対策の必要性や緊急性にみられるように，利用行 為に伴う自然環境への影響と利用者同士の接触に伴う問題では, 利用者の対応が異なった。利用の量的規制は, 自らの行動を規制 する措置を含むもので, 自然環境の保護や復元対策とは性質の異 なる面をむつ。そのため, 後者は, 一般論として肯定しやすいが, 前者は自身にも関わることとして慎重にならざるをえなかったも のと考えられる。インパクトへの不快感や対処の必要性や緊急性 についても同様な傾向が示された。背景として, 不快を感じさせ る対象の一方が人間の存在や活動であり，一方は自然環境である こと, 前者の対策は自己規制にもつながるが, 後者の対策は自己 規制を伴わなくて済むこと，前者に関する問題が国内では広く認 識されていないこと, 後者が自然保護問題として広く認識されて いることなどが考えられる。

また，他者との遭遇に $50 \%$ が不快に感じる人数（中央值）を 提示した結果, 被験者の半数近くが不快に感じると回答した結果 から, 利用体験に不快を感じない許容範囲の人数として得た值 は ${ }^{3)}$ ，収容力の設定に有効なことが再確認されたといえよう。

結果の（5）から, 利用体験の重視度と, 管理方策への支持度 合との関係は，区域間で異なった。大雪山周辺を対象とした区域 について, 利用者は, 自然との知的・感覚的接触体験を重視する に従い，管理方策を強く支持する傾向を示した。大雪山周辺では 自然との知的・感覚的接触体験を阻害しない範用で管理方策を用 意するとともに，自然との知的・感覚的接触体験を重視せず，管 理方策を支持しない利用者については, 自然環境へのインパクト が少ない活動形態に利用者を誘導することが望ましい。一方，ト
ムラウシ山を中心とする区域について，管理方策に対する支持が， 利用体験を重視する程度に左右されにくかった。このことは, 利 用体験を重視するほど管理方策を支持する利用者, 利用体験を重 視しても管理されることを嫌う利用者, 利用体験を重視しなくと も管理方策を支持する利用者など，総体としてみれば，様々な態 度を示す利用者から構成されることを示唆している。したがって, トムラゥシ山周辺区域について, 利用体験への重視度と管理方策 への支持との関連性を考慮し, 複数の集団に利用者を区分し, 各 集时に対応した管理方策の導入が望ましい。

結果の（6）から，大雪山周辺を対象とした区域について，イ ンパクトの内容が利用体験を直接的に阻害するとみられる場合, 利用体験を重視するほよ゙インパクトに対する不快感が強まる傾向 を示した。しかしながら，全体として利用体験の重視度と，イン パクトに対する不快感とでは，有意な関係が確認された場合は少 なかった。その要因として，提示項目の内容によるところが大き いとみられ，インパクトに対する不快感と，利用体験を重視する 程度との関係について，今後さらなる検討を要する。

山岳性自然公園での高山帯において利用者が重視する，自然と の知的・感覚的接触体験にふさわしい環境之活動を提供するには, 自然環境や他の利用者への影響が少ない活動への誘導（利用規制 計画）と活動に伴う自然環境への影響を抑制する管理方策（保護 施設および保護規制計画)，および利用者の望む環境の提供（利 用施設計画）と望む環境を保全するための方策（保護規制計画） を，相補的に考えることが求められる。利用計画対象や保護計画 対象となる環境や活動を, 利用体験を左右する要素として一体的 に捉えることによって，利用者に支持される実效性の高い管理方 策を展開できるであろう。なお，アンケートに回答頂いた登山者， 調査にご助力頂いた北海道大学農学部生物資源科学科花卉・造園 学研究室に対し厚く謝意を表する。

\section{参考文献}

1) Driver, B. L. and Brown, P. J (1978): The opportunity spectrum concept and behavioral information in outdoor recreation resource supply inventories, a rationale: USDA Forest Service Gen. Tech. Rep. RM-55, 24-31. Rocky Mount. Forest and Range Exp. Stan., Fort Collins, Colorado.

2 ）小林昭裕，愛甲哲也（1994）：大雪山 国立公園において利用者が利用人数や
マナーに不快を感じ始める許容限界に ついて：造園雑誌 57(5)，313-318

3 ）小林昭裕, 愛甲哲也 (1995)：大雪山 国立公園の登山者が来訪動機の充足を 期待した区域と登山経路：ランドスケー プ研究 58(5), 213-216

4) 小林昭裕 (1996): 野外レクリエーショ ン体験への期待と, 行動形態, 管理へ の考え万, 許愹限界との関連性: ラン ドスケープ研究 59(5), 133-136

5) Manfredo, M. J., Driver, R. L. and Brown, P. J (1983): A test of concepts inherent in experience based setting management for outdoor recreation areas: J. of Leisure Res. 15(3), 263-283

6) National Park Service (1995): Visitor Experience and Resource Protection Implementation Plan, June 1995, Arches National Park, Utah: 1-70. United States Department of Interior - National Park Service Denver Service Center

Summary : As more people visit a park, not only can the environmental resources be affected, but the quality of the visitor experience can be affected as well. The purposes of this study are to investigate visitors' attitude toward their experience in natural park, and to consider some efficacy of a natural park management based on visitor experience. The study was conducted at Daisetsuzan National Park during July-August in 1996. Data were collected by a mail-back questionnaire survey on mountaineers. Two areas were chosen as the subject of this study to compare visitors' attitude toward visitor experience in each area.

The major findings were as follows; (1) There was little difference between visitors' attitudes toward visitor experience in each area. (2) Opportunities for sensual and percetual contact to nature, release from social stress and fitness were rated important to visitor experience. (3) Ecological impacts were thought to be more significant elements in determining the quality of visitor experience than social impacts. (4) Visitors who attach great importace to opportunities of contacts to nature had a tendency to be eager to support a management actions to reduce ecological impacts, and be sensitive to ecological impacts. (5) Relationship between the degree of importace to visitor experience and the intensity of support to management actions varied in each area. (6) Management actions based on visitor experience in each area were considered to be effective in cooperative management with visitors in preserving natural resouces and recreational opportunities in each area of a natural park. 